\title{
PENGARUH KEMAMPUAN LITERASI MEMBACA TERHADAP PRESTASI BELAJAR SISWA SEKOLAH DASAR
}

\author{
Saeful Amri ${ }^{1}$, Eliya Rochmah ${ }^{2}$ \\ ${ }^{1,2}$ Universitas Muhammadiyah Cirebon
}

\begin{abstract}
The background of this research is the low of reading literacy skills in SDN Pegagan. The low of reading skills is thought to have an effect on student achievement as well. This is indicated by the results of student achievement that are still low. The purposes of this research are to (1) Know the reading literacy skills of student (2) Know the level of student achievement, and (3) Know the influence of reading literacy skills on student achievement in SDN Pegagan. The study design used quantitative survey research with a sample of 88 students in SDN 1,2, and 3 Pegagan. Data analysis used simple linear regression test. The results showed that (1) the reading literacy skills of students was quite sufficient at $67.53 \%$, (2) The students' learning achievement was classified as very good at $81 \%$, and (3) There was a significant influence of $5.4 \%$ between reading literacy skills and student achievement learning.
\end{abstract}

Keyword: Literacy, Reading Skill, Student Achievment, Elementary School

\begin{abstract}
Abstrak: Latar belakang penelitian ini adalah rendahnya kemampuan literasi membaca di SDN Pegagan. Rendahnya kemampuan membaca diduga berpengaruh terhadap ketercapaian prestasi belajar siswa. Hal ini ditunjukkan dengan hasil prestasi belajar siswa yang masih rendah. Tujuan penelitian adalah untuk (1) Mengetahui kemampuan literasi membaca (2) Mengetahui tingkat prestasi belajar, dan (3) Mengetahui pengaruh antara kemampuan literasi membaca terhadap prestasi belajar siswa di SDN Pegagan. Desain penelitian menggunakan penelitian kuantitatif survey dengan sampel penelitian sebanyak 88 siswa di SDN 1, 2, dan 3 Pegagan. Analisis data menggunakan uji regresi linier sederhana. Hasil penelitian menunjukkan bahwa (1) Kemampuan literasi membaca siswa tergolong cukup sebesar $67,53 \%$, (2) Prestasi belajar siswa tergolong sangat baik sebesar $81 \%$, dan (3) Terdapat pengaruh signifikan sebesar 5,4\% antara kemampuan literasi membaca dengan prestasi belajar siswa.
\end{abstract}

Kata Kunci: Literasi, Kemampuan Membaca, Prestasi Belajar, Sekolah Dasar

\footnotetext{
'Universitas Muhammadiyah Cirebon, Email: Lemination543国gmail.com

${ }^{2}$ Universitas Muhammadiyah Cirebon, Email: eliya.rochmah国umc.ac.id
} 


\section{PENDAHULUAN}

Secara tradisional, literasi dipandang sebagai kemampuan membaca dan menulis. Orang yang dapat dikatakan literat dalam pandangan ini adalah orang yang mampu membaca dan menulis atau bebas buta huruf. Pengertian literasi selanjutnya berkembang menjadi kemampuan membaca, menulis, berbicara dan menyimak (Gipayana, 2004). Sejalan dengan perjalanan waktu, definisi literasi telah bergeser dari pengertian yang sempit menuju pengertian yang lebih luas mencakup berbagai bidang penting lainnya. Perubahan ini disebabkan oleh berbagai faktor, baik faktor perluasan makna akibat semakin luas penggunaannya, perkembangan teknologi informasi dan komunikasi, maupun perubahan analogi (Abidin, Mulyati, Yunansah. 2017).

Literasi berasal dari bahasa inggris literacy yang berarti orang yang belajar. Kemampuan literasi tidak sebatas pada kemampuan membaca dan menulis. Dengan perkembangan teknologi, literasi dikaitkan juga dengan literasi sains, informasi, dan teknologi. Pada hakekatnya kemampuan baca tulis seseorang merupakan dasar utama bagi pengembangan makna literasi secara lebih luas.

Penilaian literasi Indonesia dilihat dari program OECD yaitu PISA yang selalu memperbaiki hasil surveinya tiga tahun sekali. Hasil terbaru yaitu PISA 2012 menunjukkan rata-rata literasi sains siswa sebesar 382 dengan rata-rata sebesar 501 dan berada pada peringkat 64 dari 65 negara peserta (Suwono, Rizkita, \& Susilo, 2017). Sementara tahun 2009 hasil survei PISA menunjukkan rata-rata literasi sains siswa Indonesia sebesar 383 dengan ratarata sebesar 501 dan berada pada rangking 59 dari 65 negara peserta. Hasil ini menunjukkan bahwa peringkat literasi sains siswa Indonesia menurun (Islam, Nahadi, Permanasari, 2015).

Secara data empiris kualitas pendidikan Indonesia masih belum menunjukkan peningkatan hal ini ditunjukkan dalam kategori The Primary Years Programe yang menyatakan bahwa dari 146.052 SD di Indonesia hanya delapan sekolah saja yang mendapat pengakuan dunia, demikian pula peringkat SMP hanya delapan sekolah yang masuk kategori The Middle Years Programe dari 20.918 SMP. Untuk peringkat SMA hanya tujuh sekolah yang mendapat pengakuan dunia dari 8036 SMA (Hartati, 2016). Data lain menyebutkan bahwa posisi rata-rata prestasi siswa Indonesia dapat dikatakan tergolong rendah dibandingkan dengan negara peserta studi (Pakpahan, 2017).

Data-data di atas menunjukkan bahwa tingkat literasi Indonesia masih jauh dari yang diharapkan oleh pemerintah. Literasi masih belum menjadi kebiasaan dan budaya bangsa Indonesia. Segala hal yang terkait dengan literasi masih asing bagi masyarakat Indonesia pada umumnya dan masyarakat Cirebon pada khususnya. Sehingga sekecil apapun usaha untuk memperkenalkan literasi sangat diperlukan untuk membudayakan literasi di tanah air tercinta ini.

Membudayakan literasi di sekolah tidaklah semudah membalik telapak tangan dan akan penuh dengan halangan dan tantangan. Halangan dan rintangan tersebut dapat dilihat dari bagaimana sulitnya menerapkan dan membiasakan kegiatan literasi di sekolah-sekolah dasar. Banyak faktor yang diduga mempengaruhi keberhasilan kegiatan literasi diantaranya faktor internal dan eksternal salah satunya yaitu siswa dan guru sebagai pelaku pendidikan (Yuliyati, 2014).

Budaya literasi dapat diwujudkan melalui penerapan gerakan literasi sekolah (GLS). GLS dapat dilaksanakan dengan mengintegrasikan kegiatan kourikuler, kokurikuler, dan ekstrakurikuler di sekolah (Labudasari \& Rochmah, 2019). Cara tersebut terbukti berpengaruh terhadap peningkatan kemampuan membaca siswa dan karakter mandiri siswa sekolah dasar. Secara tidak langsung kegiatan GLS tersebut terintegrasi dengan pembelajaran karena pendidikan karakter juga perlu 
diintegrasikan dengan pembelajaran khususnya di Sekolah Dasar (Rochmah, Labudasari, \& Amalia, 2019)

Peneliti memfokuskan penelitian di sekolah-sekolah dasar yang ada di Desa Pegagan Kecamatan Palimanan. Desa Pegagan memiliki tiga sekolah dasar negeri (SDN) diantaranya SDN 1 Pegagan, SDN 2 Pegagan dan SDN 3 Pegagan. Kegiatan literasi di SDN di Desa Pegagan sangat beragam dan sedikit berbeda tiap sekolahnya. Persamaan dari kegiatan literasi dari ketiga sekolah tersebut adalah kegiatan membaca buku selama 15 menit sebelum pembelajaran dimulai dan adanya kegiatan kunjungan ke perpustakaan sekolah. Dalam melaksanakan kegiatan literasi, sekolah mengalami beberapa hambatan contohnya siswa bosan dengan kegiatan membaca, kunjungan ke perpustakaan diisi dengan lebih banyak bermainnya daripada membaca buku, dan sebagainya.

Jika melihat prestasi belajar siswa SDN di Desa Pegagan diperoleh data bahwa rata-rata nilai masih berada disekitaran nilai kriteria ketuntasan minimum (KKM). Nilai yang tidak jauh dari KKM menandakan bahwa nilai kognitif siswa masih berada di bawah KKM. Nilai rapot adalah nilai kumulatif dari nilai kogitif, afektif, dan psikomotor sehingga guru bisa memberikan nilai tambahan sampai memenuhi KKM. Ratarata KKM adalah 75 sedangkan rata-rata nilai rapot dari ketiga SDN yang ada di Desa Pegagan adalah SDN 1 Pegagan 78,36, SDN 2 Pegagan 79,17, dan SDN 3 Pegagan 76,14.

Beberapa hasil penelitian terdahulu ditemukan bahwa terdapat pengaruh positif sebesar 0.55 antara gerakan literasi sekolah terhadap minat baca siswa (Faradina, 2017). Lebih lanjut hasil penelitian Farizah menghasilkan pengaruh yang signifikan antara kebiasaan membaca terhadap prestasi belajar siswa sebesar $32,8 \%$ (Farizah, 2017).

Berdasarkan hasil penelitian yang terdahulu dan permasalahan yang ada, peneliti menduga bahwa ada pengaruh antara kemampuan literasi membaca terhadap prestasi belajar siswa. Hal ini terlihat dari pembiasaan kegiatan literasi di sekolah masing-masing dan prestasi belajar yang telah diraih oleh siswa sekolahsekolah tersebut. Kemampuan literasi membaca siswa berbanding lurus dengan prestasi belajarnya.

Identifikasi masalah yang ada di sekolah dasar negeri di Desa pegagan, antara lain rendahnya tingkat literasi bangsa Indonesia, susahnya budaya literasi susah untuk berkembang karena budaya tutur bangsa Indonesia yang masih dominan, kurangnya peran masyarakat dalam mengaplikasikan Undang-Undang nomor 3 tahun 2017 tentang sistem perbukuan, kurangnya kesadaran masyarakat akan pentignya literasi, kurangnya kegiatan literasi di sekolahsekolah, kurangnya ragam dan jumlah koleksi buku yang ada di perpustakaan sekolah-sekolah, tidak mendukungnya lingkungan sekolah untuk berjalannya kegiatan literasi secara berkelanjutan, pandangan tidak ada kaitannya literasi dengan prestasi belajar pada masyarakat, malasnya siswa sekolah untuk melakukan kegiatan literasi, keterpaksaan kegiatan literasi karena hanya dipandang sebagai program pemerintah di sekolah-sekolah.

Berdasarkan permasalahan tersebut, maka dalam penelitian ini mengkaji tentang bagaimana literasi membaca siswa di sekolah dasar dam pengarihnya dilihat dari prestasi belajar siswa sekolah dasar di Desa Pegagan, Kabupaten Cirebon. Lebih lanjut tujuan penelitian ini adalah ingin mengidentifikasi kemampuan literasi membaca dan pengaruhnya terhadap prestasi belajar siswa sekolah dasar.

\section{METODOLOGI PENELITIAN}

Desain penelitian menggunakan penelitian kuantitatif korelasional yang bertujuan mengetahui hubungan antar variabel yang diteliti. Populasi yang digunakan adalah siswa kelas VI dan V yang berjumlah 344 siswa yang tersebar di 
tiga SDN di Desa Pegagan Kecamatan Palimanan. Sedangkan sampel yang diambil $25 \%$ dari jumlah populasi sebanyak 88 siswa. Berikut ini adalah sebaran jumlah sampel yang diteliti.

Tabel 1. Sebaran Jumlah Sampel

\begin{tabular}{ccc}
\hline No. & Nama Sekolah & Sampel \\
\hline 1 & SDN 1 Pegagan & 27 \\
2 & SDN 2 Pegagan & 44 \\
3 & SDN 3 Pegagan & 17 \\
& Total Jumlah Sampel & 88 \\
\hline
\end{tabular}

Instrumen yang digunakan yaitu angket tertutup dengan 25 item yang diuji validitas dan reliabelitasnya terlebih dahulu. Analisis data menggunakan uji prasyarat analisis untuk mengetahui normalitas, homogenitas dan linearitas kemudian data dianalisis menggunakan teknik analisisis regresi linier sederhana untuk menguji hipotesis.

\section{HASIL PENELITIAN DAN PEMBAHASAN}

Hasil uji prasyarat didapatkan bahwa nilai uji normalitas varibel kemampuan literasi membaca siswa (X) sebesar 0.069 dan variabel prestasi belajar siswa (Y) sebesar 0.092 yang artinya data kedua varibel berdistribusi normal. Hasil uji homogenitas didapatkan nilai variabel $\mathrm{X}$ sebesar 1.393 dan varibel Y sebesar 0.911 yang artinya data kedua varibel homogen. Sedangkan untuk hasil uji liniearitas didapatkan variabel $\mathrm{X}$ sebesar 1.177 dan variabel $Y$ sebesar 0.745 yang artinya data kedua variabel linier. Sehingga data layak untuk diuji hipotesis. Untuk lebih jelasnya, berikut ini adalah hasil uji prasyarat analisis data variabel $\mathrm{X}$ dan $\mathrm{Y}$.

Tabel 2. Hasil Uji Prasyarat

\begin{tabular}{llll}
\hline No. & Uji & \multicolumn{2}{l}{ Variabel } \\
& & $\mathrm{X}$ & $\mathrm{Y}$ \\
\hline $\mathbf{1}$ & Normalitas & 0.069 & 0.092 \\
$\mathbf{2}$ & Homogenitas & 1.393 & 0.911 \\
$\mathbf{3}$ & Linearitas & 1.177 & 0.745 \\
\hline
\end{tabular}

Hasil Uji Korelasi dan Uji Hipotesis

Berdasarkan uji korelasi yang sudah dilakukan ditemukan bahwa kemampuan literasi membaca memiliki hubungan positif yang signifikan dengan prestasi belajar siswa. Nilai signifikansi yang didapat sebesar 0,3 yang lebih rendah dari 0,05 yang berarti dua variabel memiliki hubungan yang positif. Maksud hubungan yang positif adalah semakin baik kemampuan literasi membaca siswa maka semakin baik pula prestasi belajarnya.

Besarnya hubungan kemampuan literasi membaca dengan prestasi belajar adalah 0,232 atau 23,2\% saja. Hubungan ini terbilang sangat rendah karena masih banyak ditemukan siswa yang kemampuan literasi membacanya rendah memiliki prestasi belajar yang sangat baik dan siswa yang literasi membacanya terbilang baik memiliki prestasi yang di bawah nilai ratarata prestasi belajar sampel.

Untuk nilai pengaruh kemampuan literasi membaca terhadap prestasi belajar didapatkan nilai 5,4\%. Nilai tersebut masih sangat rendah karena kemampuan literasi membaca hanya punya pengaruh $5,4 \%$ terhadap prestasi belajar dan sisanya yaitu 94,6\% dipengaruhi oleh variabel-variabel lain. Hasil penelitian ini didukung oleh hasil penelitian Farizah yang menyatakan bahwa ada pengaruh yang signifikan antara kebiasaan membaca terhadap prestasi belajar siswa (Farizah, 2017).

\section{PEMBAHASAN}

Kemampuan literasi membaca dapat dilihat dari (1) jumlah dan variasi bahan bacaan, (2) frekuensi peminjaman bahan bacaan di perpustakaan, (3) jumlah kegiatan sekolah yang berkaitan dengan literasi membaca, (4) terdapat kebijakan sekolah mengenai literasi membaca, (5) terdapat komunitas membaca di sekolah (Kemendikbud, 2017).

Penilaian membaca yang dilakukan PISA memperhatikan tiga hal berikut, yaitu (1) jenis teks yang digunakan (jenis teks baik dari segi media, format, jenis, maupun lingkungan), (2) aspek pemahaman (mengakses dan mengambil informasi dari teks, mengintegrasikan dan menafsirkan isi bacaan, merefleksi dan mengevaluasi teks, dan menghubungkan isi teks dengan 
pengalaman pembaca), dan (3) aspek situasi sosial (personal, masyarakat umum, pendidikan, dan dunia kerja) (OECD, 2013). Indikator kemampuan literasi membaca dari penelitian ini adalah: (1) Jenis teks yang digunakan (jenis teks baik dari segi media, format, jenis, maupun lingkungan), (2) Frekuensi peminjaman bahan bacaan di perpustakaan, (3) Jumlah kegiatan sekolah yang berkaitan dengan literasi membaca, (4) Terdapat komunitas membaca di sekolah, dan (5) Aspek pemahaman (mengakses dan mengambil informasi dari teks, mengintegrasikan dan menafsirkan isi bacaan, merefleksi dan mengevaluasi teks, dan menghubungkan isi teks dengan pengalaman pembaca).

\section{Kemampuan Literasi Membaca Siswa Sekolah Dasar di Desa Pegagan}

Tingkat kemampuan literasi membaca siswa SDN di Desa Pegagan Kecamatan Palimanan berada pada nilai $67,53 \%$. Nilai tersebut diperoleh dari nilai rata-rata kemampuan literasi membaca dan juga diperoleh dari perhitungan rumus nilai angket yang sudah ditentukan. Nilai 67,53\% menunjukkan bahwa kemampuan literasi membaca siswa SDN di Desa Pegagan termasuk ke dalam kategori cukup. Data ini didukung dengan kegiatan literasi membaca di SDN yang baru digalakan dua tahun belakangan. Kegiatan literasi membaca yang baru dua tahun ini masih banyak menghadapi halangan dan rintangan sehingga pelaksanaannya masih jauh dari maksimal.

Tingkat kemampuan literasi membaca siswa SDN di Desa Palimanan secara berurut adalah SDN 1 Pegagan dengan nilai $68,4 \%$ yang diaktegorikan cukup, SDN 2 Pegagan dengan nilai $67,53 \%$ yang berkategori cukup, dan SDN 3 Pegagan dengan nilai $66,18 \%$ yang berkategori cukup pula. Ketiga sekolah tersebut memiliki nilai kemampuan lietrasi membaca yang berada dikategori yang cukup dengan selisih nilai yang sangat sedikit. Berikut ini adalah perbandingan kemampuan literasi membaca setiap sekolah dasar.

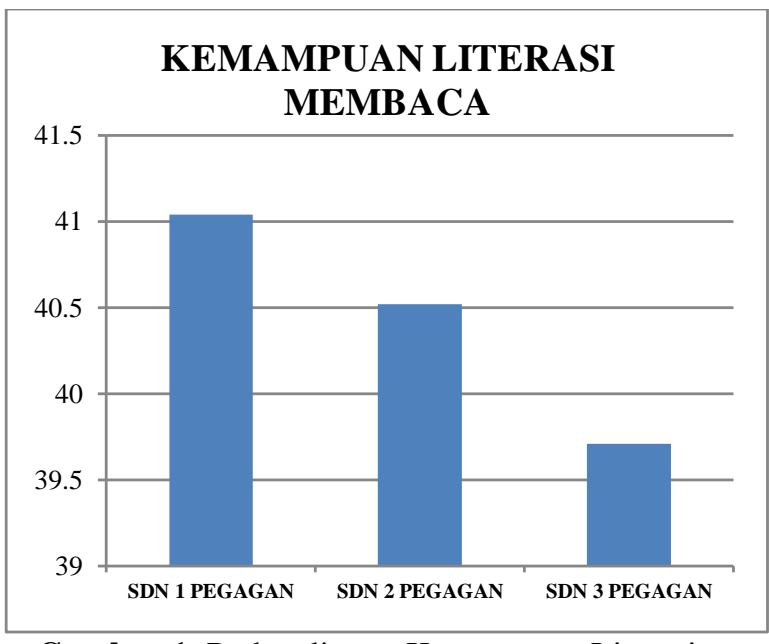

Gambar 1. Perbandingan Kemampuan Literasi Membaca

\section{Prestasi Belajar Siswa Sekolah Dasar di Desa Pegagan}

Nilai rata-rata prestasi belajar siswa SDN di Desa Pegagan adalah 81 dengan nilai tengah 80,5 dan nilai yang sering muncul 84. Nilai terendah di angka 73 yang berarti nilai prestasi belajarnya baik. Nilai tertinggi adalah 92 yang berarti nilai pretasi belajarnya sangat baik.

Tingkat prestasi belajar siswa SDN di Desa Pegagan adalah $81 \%$ yang berarti sangat baik dengan $43,18 \%$ di kategorikan baik dan $56,82 \%$ dinyatakan sangat baik. Hal ini dikarenakan nilai pretasi yang diambil adalah nilai rapot yang penilaiannya bukan hanya dari nilai kognitif semata. Penilaian afektif dan psikomotor juga mempengaruhi nilai sehingga menjadi nilai kumulatif yang baik. Sejalan dengan kurikulum 2013 bahwa pembelajaran literasi tidak hanya diorientasikan untuk meningkatkan kemampuan kognitif saja melainkan diorientasikan juga kepada pengembangan sikap, keterampilan, dan pengetahuan siswa (Abidin, Mulyati, Yunansah. 2017).

Tingkat prestasi belajar siswa sekolah dasar di Desa Pegagan Kecamatan Palimanan secara berurut adalah SDN 2 Pegagan dengan nilai $84,2 \%$ yang berada dikategori sangat baik, SDN 1 Pegagan dengan nilai $78,7 \%$ berada pada kategori baik, dan SDN 3 Pegagan dengan nilai $76,35 \%$ dikategori yang baik pula. Prestasi 
belajar yang diaktegorikan sangat baik hanyalah SDN 2 Pegagan, sedangkan SDN 1 Pegagan dan SDN 3 Pegagan masuk kategori prestasi belajar yang baik.

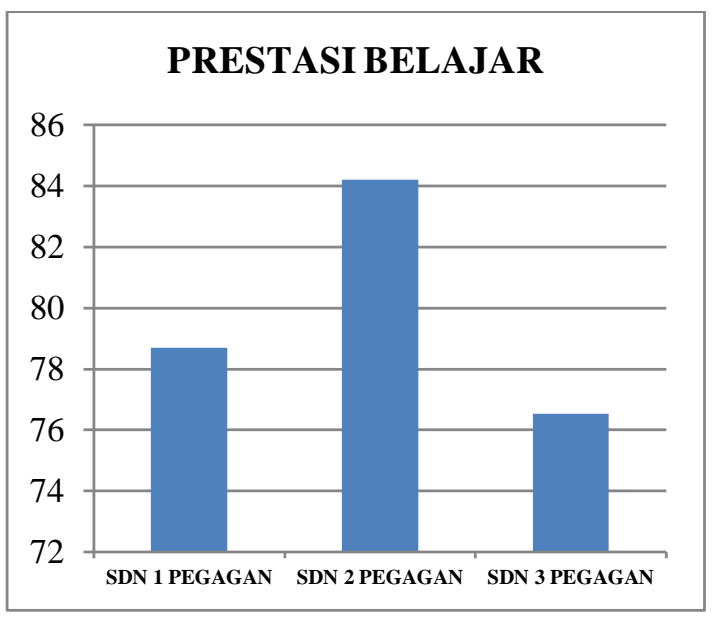

Gambar 2. Perbandingan Prestasi Belajar

\section{Pengaruh Kemampuan Literasi Membaca Terhadap Prestasi Belajar Siswa Sekolah Dasar Di Desa Pegagan}

Berdasarkan uji korelasi yang sudah dilakukan ditemukan bahwa kemampuan literasi membaca memiliki hubungan positif yang signifikan dengan prestasi belajar siswa. Nilai signifikansi yang didapat sebesar 0,3 yang lebih rendah dari 0,05 yang berarti dua variabel memiliki hubungan yang positif. Maksud hubungan yang positif adalah semakin baik kemampuan literasi membaca siswa maka semakin baik pula prestasi belajarnya. Besarnya hubungan kemampuan literasi membaca dengan prestasi belajar adalah 0,232 atau $23,2 \%$ saja. Hubungan ini terbilang sangat rendah karena masih banyak ditemukan siswa yang kemampuan literasi membacanya rendah memiliki prestasi belajar yang sangat baik dan siswa yang literasi membacanya terbilang baik memiliki prestasi yang di bawah nilai ratarata prestasi belajar sampel.

Untuk nilai pengaruh kemampuan literasi membaca terhadap prestasi belajar didapatkan nilai $5,4 \%$. Nilai tersebut masih sangat rendah karena kemampuan literasi membaca hanya punya pengaruh $5,4 \%$ terhadap prestasi belajar dan sisanya yaitu
94,6\% dipengaruhi oleh variabel-variabel lain.

\section{KESIMPULAN}

Penelitian menunjukkan bahwa kemampuan literasi membaca siswa SDN di Desa Pegagan Kecamatan Palimanan berada di tingkat cukup, yaitu $67,53 \%$. Tingkat kemampuan literasi membaca ini dari indikator-indikator jenis teks, frekuensi peminjaman bahan bacaan, jumlah kegiatan literasi sekolah, komunitas membaca, dan aspek pemahaman siswa terhadap bacaan. Prestasi belajar siswa SDN di Desa Pegagan Kecamatan Palimanan sangat baik dengan $81 \%$. Kemampuan literasi membaca dengan prestasi belajar siswa SDN di Desa Pegagan Kecamatan Palimanan memiliki hubungan positif dengan nilai $23,2 \%$. Nilai hubungan tersebut terbilang rendah karena kurang optimalnya kegiatan literasi membaca yang dilakukan sekolah. Sedangkan pengaruh kemampuan literasi membaca terhadap prestasi belajar hanya sebesar $5,4 \%$. Melihat hasil tersebut, siswa seharusnya lebih meningkatkan kemampuan literasi membaca sehingga ketercapaian prestasi yang dihasilkan dapat maksimal. Disamping itu, sekolah sebaiknya mendukung penuh program literasi membaca yang diselenggarakan di sekolah dasar agar kemampuan literasi membaca siswa dapat dimiliki siswa sekolah dasar pada khususnya dan bangsa Indonesia pada umumnya dapat meningkat sehingga menjadi bangsa yang tidak kalah dengan bangsa lain yang memiliki kemampuan literasi yang lebih tinggi.

\section{DAFTAR PUSTAKA}

Abidin, Y. Mulyati, T. Yunansah. H. (2017). Pembelajaran Literasi: Strategi Meningkatkan Kemampuan Literasi Matematika, Sains, Membaca, dan Menulis. Jakarta: Bumi Aksara.

Faradina, N. (2017). Pengaruh Program Gerakan Literasi Sekolah Terhadap Minat Baca Siswa di SD Islam Terpadu Muhammadiyah An-Najah Jatinom Klaten. Jurnal Hanata Widya, 6(8), 60- 
69.

Farizah, T. (2017). Pengaruh Kebiasaan Membaca Terhadap Prestasi Belajar Siswa pada Mapel Bahasa Indonesia di MI Ma'arif04 Gentasari Kroya Cilacap. IAIN Purwokerto.

Gipayana, M. (2004). Pengajaran Literasi dan Penilaian Portofolio dalam Konteks Pembelajaran Menulis di SD. Jurnal Ilmu Pendidikan, 11(1), 1-12.

Hartati, T. (2016). Multimedia Dalam Pengembangan Literasi di Sekolah Dasar Terpencil Jawa Barat. Edutech, 15(3), 303.

Islam, A., Nahadi., Permanasari, A. (2015). Hubungan Literasi Sains dan Kepercayaan Diri Siswa Pada Konsep Asam Basa. JPPI, 1(1), 16-25.

Kemendikbud. (2017). Materi Pendukung Literasi Baca Tulis. Jakarta: Kementerian Pendidikan dan Kebudayaan.

Labudasari, E., \& Rochmah, E. (2019). Pengaruh gerakan literasi sekolah terhadap karakter mandiri siswa di SDN Kanggraksan Cirebon. Premiere Educandum: Jurnal Pendidikan Dasar Dan Pembelajaran, 9(1), 57. https://doi.org/10.25273/pe.v9i1.4254

OECD. (2013). Assessment and Analytical Framework: Mathematics, Reading, Science, Problem Solving and Financial Literacy. In Echinoderms: Durham Proceedings of the 12th International Echinoderm Conference. https://doi.org/10.1201/9780203869543c92

Pakpahan, R. (2017). Faktor-faktor Yang Memengaruhi Capaian Literasi Matematika Siswa Indonesia dalam PISA 2012. Jurnal Pendidikan Dan Kebudayaan, 1(3), 331-348.

Rochmah, E., Labudasari, E., \& Amalia, N. (2019). Pengembangan Media Berbasis Teknologi Augmented Reality Bermuatan Wawasan Kebangsaan Pada Tokoh Kepahlawanan. EduHumaniora| Jurnal Pendidikan Dasar Kampus Cibiru, 11(1), 10.

https://doi.org/10.17509/eh.v11i1.11489

Suwono, H., Rizkita, L., \& Susilo, H. (2017). Peningkatan Literasi Saintifik Siswa Sma Melalui Pembelajaran Biologi Berbasis Masalah Sosiosains. Jurnal Ilmu
Pendidikan, 21(2), 136-144. https://doi.org/10.17977/jip.v21i2.8367

Yuliyati. (2014). Model budaya baca-tulis berbasis balance literacy dan gerakan informasi literasi di SD. Jurnal Ilmu Pendidikan, 20(1), 117-126. https://doi.org/10.17977/JIP.V20I1.4386 